\title{
ANALYSIS ON THE PRINCIPLES OF MAQASID SHARIAH IN ISLAMIC HOTELS
}

\section{AZIZAH MUSA}

Faculty of Business and Entrepreneurship, University Malaysia Kelantan, 16400, Kota Bharu, Kelantan, Malaysia. (Phd Candidate of Universiti Sultan Zainal Abidin) azizah.m@umk.edu.my* (Azizah Musa)

\section{ABSTRACT}

Tourism industry's development recently is irrefutably hit the international awareness and sparked the local interest. Statistical data of Tourism Malaysia showed a rise of 6.8 per cent tourists' growth from 2018 leads to the figure of 13.35 million international tourists in 2019. Malaysia, as a multicultural country with the majority of $63.7 \%$ of the population are Muslims, should take active steps to intensify the ways in discovering the market needs. Desires of Islam need to be cleared and the spirit of Maqasid Shariah have to be manifested equally to the Muslim and the non-Muslim. This paper therefore, aims to discuss on the necessity to clarify the relevancy of having Islamic hotel as to align with the basic principles of Maqasid Shariah and to see whether the current practices and policies are coherent with the Maqasid. This qualitative study embarked on content analysis from a few relevant policies and previous studies. In addition, an in-depth interview was conducted with two relevant local authorities. Having analyzed the information gained, it was found that as now, no specific legislative Islamic hotel policy was in place. However, few limited existing guidelines are found to intrinsically applying the Principles of Maqasid Shariah. The results presented here have profound implications on a proper drafting of an inclusive Islamic Hotel policy in the future. It is hoped that Maqasid will be set as a benchmark for the future policy setting as this will boost the confidence of the tourists in visiting the country.

Keyword: Hotel attributes, Islamic hotel, Islamic tourism, Maqasid Shariah, Muslim friendly hotel, policy, and guidelines. Article Received: 18 October 2020, Revised: 3 November 2020, Accepted: 24 December 2020

\section{Introduction}

The growth of the halal industry in international level becomes an attention-grabbing matter to be looked upon and to have further exploration on how people foresee the vista of this industry. Amusingly, tourism industry is now contributing to RM41.69 billion to the country's revenue for the first half of the year 2019. With this welcoming development, initiatives of the government to further develop the industry is essential. Malaysia population itself is constantly increasing to a total $32,392,828$ million in 2019 , a $2 \%$ rise of last year population. By this figure, $63.7 \%$ are Muslims. Therefore, the progress of halal industry need to be closely monitored as halal industry is seen to be a fast emerging sector and has attracted various parties concern particularly in Malaysia as a country which worldly acknowledged as the pioneer and leader in Halal world (Musa et al., 2019). Many scholars had highlighted on the necessity of exploring and creating the manufacturing of halal products and services in the realm of hospitality. What was commonly agreed is that in order to venture into the halal market's segment, accommodation industry players, particularly hotels and residence practitioners, should be proactive in their ways in attracting Muslim customers. (Jeaheng, Al-Ansi, \& Han, 2019). Due to this, tourism and hospitality industry is striving themselves to be at par with the other halal sectors and enthusiastically producing Islamic tourism merchandises. Thus, Islamic Based Hotels which alternately be termed as "Shariah Compliant Hotel" or "Muslim-Friendly Hotel" (MFH) are among the products which need attention to accommodate this demand.

Among the ten Organization of Islamic Cooperation (OIC) countries, Malaysia was awarded as the best top halal friendly holiday destination based on facilities and services offered to Muslim tourists for 9 years in rank ("Global Muslim Travel Index 2018.," 2019). Only in 2019 ranking, Malaysia shared this top rank position with Indonesia (Crescent Rating, 2019). In Malaysia, the overall guideline for halal food has been endorsed by Malaysian Islamic Development 
Department (JAKIM) and by States Religious Councils. Despite of this legislative guideline on halal, a question mark remains as to the creation of guidelines and proper policy in the development of Islamic Hotel in Malaysia as to enable in convincing and accommodating any interested hoteliers. According to President of Malaysian Association of Hotels, Dato' Ilyas Bin Zainol Abidin (2013), "There are general non-bidding guidelines but no clear cut standards and criteria for the services of halal hotel". Due to this, it should be proudly noted here that since 2015 Malaysia Standard Department, had come out with MuslimFriendly Hospitality Services Standards (MS 2610: 2015) which at least become Malaysia standard on this matter.

Many scholars are of the view that, in order to grasp the halal market, hotels and residence operators as, play an important role in attracting Muslim customers. However, prior to this implementation, a deeper understanding of the needs, behaviors and preferences of the Muslim customer is needed (Battour \& Ismail, 2016). One of the concerns is on the implementation of the laws and standards (Rahman, Faudzi, Ahamat, \& Ghadas, 2016). The issue for concern is whether all these laws and policies were being drafted based on Maqasid Shariah. This become the point in concern as Maqasid plays an important role in the process of drafting the law and hence governing all sphere of human actions and conducts. Any policy or regulation introduced by the government of a country must be aligned with the Islamic principles, to protect Muslims interests. (Nor et al., 2012).

\section{Literature Review}

\subsection{World Travel Market}

According to UNWTO, tourism is when a person travels to and stay in a place outside their usual place for less than one year for the purpose of relaxation, business and others. A tourism is also defined as societal, cultural, and monetary factor that involves the movement of persons to countries or sites outside their homes for individual or business/professional aims (Arshad, Iqbal, \& Shahbaz, 2018).

International tourism activities since past few centuries become one of economic and social contributor throughout the globe. According to the latest UNWTO World Tourism Barometer international tourist arrivals reach a total of 1,235 million. Due to this, the year of 2017 has been declared by the United Nations as the International Year of Sustainable Tourism for Development. (www2.unwto.org, retrieved 9/10/2019). UNWTO Secretary-General Taleb Rifai in one press statement was then claimed that "Tourism has shown extraordinary strength and resilience in recent years, despite many challenges, particularly those related to safety and security. Yet, international travel continues to grow strongly and contribute to job creation and the wellbeing of communities around the world".

Meanwhile, Malaysia travel industry marked a progressive tourists' arrivals of $\mathbf{4 . 8 \%}$ for the month of January until May 2019 which brings to a total of 10,954,014 tourist influxes compared to the same period last year. The ASEAN countries meanwhile still being the biggest contributor of international tourist influxes to Malaysia with a contribution of $69.2 \%$, reflecting a $4.7 \%$ increase to $\mathbf{7 , 5 8 4 , 1 2 8}$ tourists compared to $\mathbf{7 , 2 4 5 , 5 7 0}$ tourists during the same period last year. The tourists of Indonesia, Singapore and Thailand are the main contributors towards this statistic (https://www.tourism.gov.- retrieved 13/11/2019)

According to (Chanin et al., 2015) tourism need to be managed properly in order to the social and natural environment in the host area and reduce the negative effects significantly and this is what being called as a sustainable tourism.

The problem of tourism in the OIC countries including Malaysia nowadays are diverse as each country has its own tourism features, level of development and national development priorities and policies. The main concern for Malaysia is however remains as to developing tourism industry in line with the needs of Islam. 


\section{Islamic Tourism Landscape}

"Halal tourism" is now becoming a new target in the travel industry and can be regarded as the most forceful development, which provides holiday destinations for Muslims as it need to comply with the Islamic rules. The term is interchangeably used as "Islamic tourism" and it has been seen as a new tourism product globally. The emergence is due to the fact that many of the Muslim majority markets now are the fast-emerging economies (Suid, Nor, \& Omar, 2017).

"Halal" meanwhile is an Arabic term which means permissible. Muslims are obliged to follow all the Shariah principles in leading their way of lives. Due to this, Muslims absolutely need to put their efforts to follow what have been designated for them by Al-Quran and Al-Sunnah, including in the sphere of travel and tourism. Therefore, the development and improvement of Islamic hotel is suggested as a way to attract more tourists particularly Malaysia.

Some researchers opined that, travelling matters and religions are interrelated. Therefore, religion is one of the important reasons underlying tourism development. This relationship between religion and tourism, is mostly examined by many literatures and scholars under the purview of religious, faith, pilgrimage, Islamic as well as halal tourism (Şen Küpeli, Koc, \& Hassan, 2018). Besides these huge of literatures, very little discussion was made on the extent of the religious product preference of a Muslim when joining a tourism activity. (Eid \& El-Gohary, 2015).

Halal tourism is claimed to be one of the most rewarding and welcoming tourism product. It come with a wide range of potential for businesses and travel related entities (Mohammed Jemal AHMED,2018) According to Mastercard \& Cresent rating (2017), it is also one of the world's highest spending tourist markets. It came to fulfil the demands of Muslim tourists who want to get an exclusive holiday package which adhered to Islamic values and principles. (Battour \& Ismail, 2016; Elasrag, 2016), and (World Travel Market [WTM], 2007). Halal tourism has recently been gaining popularity, and is now become one of the fastest growing niche in tourism industry (Elasrag, 2016). With a spending of about USD 155 billion in 2016, the Halal tourism market is a noteworthy contributor to the overall Muslim consumer market - which is estimated to be worth USD 2 to 3 trillion across various Halal industries of food, lifestyle and services (Mastercard \& Crescentrating, 2017:3). It was world recognition that Malaysia is a forerunner in introducing an all-inclusive standard for halal merchandises (Shafaei \& Mohamed, 2017).

The latest statistic of 2019 revealed, 130 countries were become destinations of halal tourism. Of which 46 were Muslim countries destinations and 82 non-Muslim destinations (Mastercard \& Crescentrating, 2019). In 2019, Malaysia, Indonesia, United Arab Emirates, Turkey, Saudi Arabia, Qatar, Morocco, Oman, Bahrain and Iran respectively were top 10 destinations of Halal tourism from Muslim Countries whereas Singapore Thailand, United Kingdom, South Africa, Hong Kong, Japan, Taiwan, France, Spain and United States respectively were from non-Muslim Countries (Mastercard \& Crescentrating, 2019). From Muslim countries, Malaysia and Indonesia in 2019 are now sharing the same rank as the best destination of Halal tourism whereas from nonMuslim countries Singapore is positioning itself as the best destination for Muslim holidays.

\subsection{Islamic Hotel Concept and Practices}

The use of the terms "Islamic tourism" and "halal tourism" has brought along the establishment of various types of hotels claiming the special attention to Islamic rules and principles. Such types of hotels as Shariah, dry, Islamic, halal, muslim friendly and conservative hotel are among the primary statements used for such businesses in literature and industry (e.g. Ahmat, Ritzuan, \& Zahari, 2012; Henderson, 2010; Stephenson, 2014), and (Musa et al., 2017).

According to Salleh, (Salleh, Hamid, Hashim, \& Omain, 2014), many experts opined that there is a bright future of $\mathrm{SCH}$ in spite of its slow progress. Many international chain hotels operating in the Middle East, such as the Landmark Hotel Group and The Serai Group, had sparked an interest to 
open $\mathrm{SCH}$ as early as 2006 ; however, the progress is delayed because many parts of the world were affected by economic downturn in 2008 (Salleh et al., 2014; Tarrant, 2010).

This term of Shariah-Compliant Hotels ( $\mathrm{SCH}$ ) was used by (Yusuf, 2009) to mean hotel that provides services and makes financial transactions based on completely Shariah principles, not limited to serve halal food and drinks but also for the health, safety, environmental and economic aspects for the benefit of everyone.

In response to the establishment of $\mathrm{SCH}$ hotel in Malaysia, there arise some hotels which provide the most common facilities to fulfil the Muslim tourists' needs and known as 'Muslim friendly hotel' (Samori \& Sabtu, 2014). Among the hotels are Grand Bluewave Hotel in Shah Alam, PNB Darby Park Hotel and Putra Hotel in Kuala Lumpur, Perdana Hotel in and Tabung Haji Hotel in Terengganu (Musa et al., 2019).

In addition, the influx of Middle East tourists to Malaysia provides immense opportunities for $\mathrm{SCH}$ when these hotels are attractive to these tourists for accommodation which in turn will increase the SCH profits (Salleh et al., 2014).

Despite huge academic discussion has been done on the characteristics of SCH in term of its facilities provided to their guests, the attribution of $\mathrm{SCH}$ is not only guest-centred but also covers the perspective of service providers. The staff of the hotel must also adhere to the Shariah principles such as wearing proper attire, speak properly, give salam and observe their prayers and their duty honestly (Sulaiman \& Maidin, 2018). In addition, the financial management of the hotel should always be aligned with the Shariah principles. differentiates between Shariah Compliance Hotel and Muslim-Friendly Hotel and Services.

(Jais, 2016) compared Shariah Compliant Hotels and Muslim-Friendly Hotels and Services. According to him, unlike $\mathrm{SCH}$, the application or adoption of Shariah law is very limited in the category of Muslim-Friendly Hotel and Services. July 2019 marked a memorable moment for Malaysia tourism industry when 12 hotels throughout the country were recognized as Muslim
Friendly Hotel by Islamic Tourism Centre having fulfil all the needed requirements to get such an outstanding recognition. This accreditation is a combined work of the Department of Standards Malaysia and ITC, is said to be the only recognition of its kind in the world issued by a government agency. ITC's director general, Abdul Khani Daud, said: "The Muslim Friendly Accommodation Recognition is a continuation of the Star Ratings conducted by the Ministry of Tourism, Arts and Culture (MOTAC). Most of the Muslim-friendly components already existed in the Star Ratings criteria. It emphasizes elements such as the hotel providing at least one halal-certified restaurant; conducive facilities such as prayer mats, qiblat direction, and daily prayer time information; and segregated swimming pools, spa and gymnasium."'The hotels are: Movenpick Hotel \& Convention Centre KLIA; Hotel Grand Bluewave Shah Alam; The Light Hotel Penang; Adya Hotel Langkawi; PNB Perdana Hotel \& Suites On the Park Kuala Lumpur; PNB Perdana Kota Bharu; TH Hotel \& Convention Centre Terengganu; Zenith Putrajaya; Tamu Hotel \& Suites Kuala Lumpur; PNB Ilham Resort Port Dickson; Hyatt Regency Kota Kinabalu; and Grand Darul Makmur Hotel in Kuantan ("Malaysia Establishes Official Recognition for Halal-Friendly Hotels. ," 2019).

4. Maqasid Shariah as the Basis for Ruling 'Maqasid' refers to a purpose, objective, principle, intent, goal, end, telos (Greek). Maqasid of the Islamic law are the objectives and purposes as well as principles behind Islam. The primary objective of Shariah is to benefit people and to provide the best for them worldly and in the hereafter. Shariah targets at safeguarding the people or protecting them against corruption and evil. (Afridi, 2016). The Holy Qur'an stressed the main purpose of Shariah in (Al Anbiya: 107). when it reads:

And We have sent you (O Muhammad) not but as a mercy for the "Alamin (mankind, jinns and all that exists)

This verse surpasses all barriers that divide humanity. The word "mercy" in this verse includes compassion, kindness, goodwill, and beneficence. 
In discussing the above verse, Ibn Qayyim al-Jawzi explained that Shariah main interest was to protect people's interests and sheltered them from any harm in this world and the hereafter. (Afridi, 2016). According to (Kamali, 2000), Shari'ah is often described as 'diversity within unity'-diversity in interpretations but unity in the goals and objectives. Further Shariah is defined by Al-Qardawi as the judgments of Allah and his Prophet as laid down in the Quran and the Sunnah

Maqasid Shariah plays a vital role in the law creation's process as they constitute the primary purpose of Islam which is achieved through the process of law legislation.

Knowledge of the Maqasid Shariah is of extreme importance in the process of ijtihad (legal reasoning/derivation of rulings), especially in the realm of siyasah shar'iyyah, in contemporary era. This is due to the increased numbers of new issues and problems that were previously not known to classic scholars, hence remained unsolved in respect of their legal status and value. In confronting these new issues and problems, Muslims scholar have taken various positions.

Categories of Maqasid Shariah are divided into three main spheres i.e The Essentials (alDaruriyyat), The needs (al-Hajiyyat) and The Complementary Interests (al-Tahsiniyyat).

\section{The Essentials (al-Daruriyyat)}

The Daruriyyat are the matters which the religion and worldly affairs of the people depend on; neglecting them will lead to full commotion and disorder which lead to an undesirable end. It must be protected and all measures aimed at protecting them should be taken, whether by individuals or by government authorities. The essentials (daruriyyat) can be sub-divided into five fundamental values (al-daruriyyat al-khams), which become necessities in human life. These five values are:

1. Safeguarding of ad-din/ religion

2. Safeguarding of life

3. Safeguarding of dignity or lineage

4. Safeguarding of intellect

5. Safeguarding of property
6. Five Basic Rights as Prescribed by Maqasid Shariah:

1. Safeguarding of Religion is the most significant value that must be safeguarded by a Muslim. It is obligatory on every Muslim to protect his aldin at any time. Protection of al-din at the individual level is achieved through the observance of various types of 'worship, such as praying five times a day, fasting, zakat and hajj. Implementing all these rituals will increase a person's faith and because it will be a shield that protects people from sin or fall away and engage in actions that will eliminate its din.

2. Safeguarding of Life: is definitely important and valuable to everyone. It must be sheltered in all situations and in this case, there is no difference between the lives of rich and poor, leaders and subordinates, Muslim and nonMuslim. Protecting life is equally important and mandatory for every individual and society. The Qur'an emphasises this point in verse 33 of Al- Isra:

"And do not kill anyone who Allah has forbidden, except for a just cause. And whoever is killed (intentionally with hostility and oppression and not by mistake), We have given his heir the authority [(to demand Qisas, Law of Equality in punishment or to forgive, or to take diyah (blood money)].

3. Safeguarding of Dignity or Lineage (al 'Ird). One important element in the life of a person is of course life's dignity. Islam put serious emphasis on the dignity of a person and highlight the importance of protecting the dignity. Dignity protection, including protecting the rights of individuals to privacy and not to expose or accuse others of any bad or immoral behaviour which by the end may jeopardize one's dignity and lineage.

4. Safeguarding of Intellect or Mind (al-'Aql) is the most treasurable gift from Allah S.W.T to mankind. Allah S.W.T.has ordered that everyone must sheltered this gift from any kind of crime or anything that may cause destruction. Islam allows space and freedom 
for followers to express their views and tolerated different views and opinions as guided by the Qur'an and Sunnah. Mind need security protection from anything that might harm the ability and brain function. This includes the consumption of alcohol or similar substances that would interfere with brain function

5. Safeguarding of Property (al-Mal): Acquiring property is a basic human need. Everyone need property in term of money and any other assets and would like to have all the essential protection and security for his/her property. Islam has guided that everyone should only obtain the property through a valid mean and way without transgress others right.

\section{Priorities Within the Maqasid}

The discussion on priorities within Maqasid was made by few Islamic Scholars as Maqasid indicates that some principles are prevail over the others in case of a clash between them. further outlined three important rules that govern the concept of Maqasid. Rule 1 outlined that, the stronger interest shall prevail over the weaker interest. As thus, the preservation of religion has preference over the preservation of life, life over progeny and so on. In the same way, the Daruriyyat have priority over the Hajiyyat, and Hajiyyat take preference over Tahsiniyyat. Rule 2 meanwhile outlined that the public interest prevails over private interest and Rule 3 stressed the definitive interest prevails over the probable. This rule number 3 was however sparked long discussion among scholars.

\section{Materials And Methods}

This study employed an approach of Qualitative research in which it focused on an in-depth interview with key stakeholders to answer all the intended research questions. Interviews were normally for lasted 1-2 hours and this interview were definitely being audiotaped to ease the process of transcribing and analyzing the raw data. After the initial interviews was done to the first identified informant, the informant was genuinely requested to recommend other stakeholders whom they thought had relevant characteristics and knowledge about the study topic. This concept more towards a snowball sampling technique. (Berg, 2004). Therefore, in this study, an interview with two prominent public authorities directly involve in law and policy drafting especially those involving Islamic policies were properly transcribed and analysed. Categories based on relevant themes were established after examination of the data. On top of the interview analysis, an analysis towards a few established public policies relevant to the topic were also being employed. The data were sorted into categories using key words as codes.

\section{Results And Discussions}

It is noticed that some attributes of the common law and Shariah compliant companies are different (Hassan, Abd Ghadas, \& Rahman, 2012). It is suggested the interior design of guest rooms should reflect Islamic art and culture and adhere to Islamic financial management, such as contribution of alms or zakat. (Kamali, 2000) highlighted on the requirement of Islamic hotel vicinity to mosque or surau, and hotel's restaurant serving halal food and beverages in addition to other commonly agreed requirements such as prayer mat, prayer beads, qiblat direction, and separate utensils for Muslim guests. (Rosenberg \& Choufany, 2009) set the criteria of "Shariah Complian hotel" as to consist of three aspects namely, operations, interior design and financial as outlined in Figure 1. 

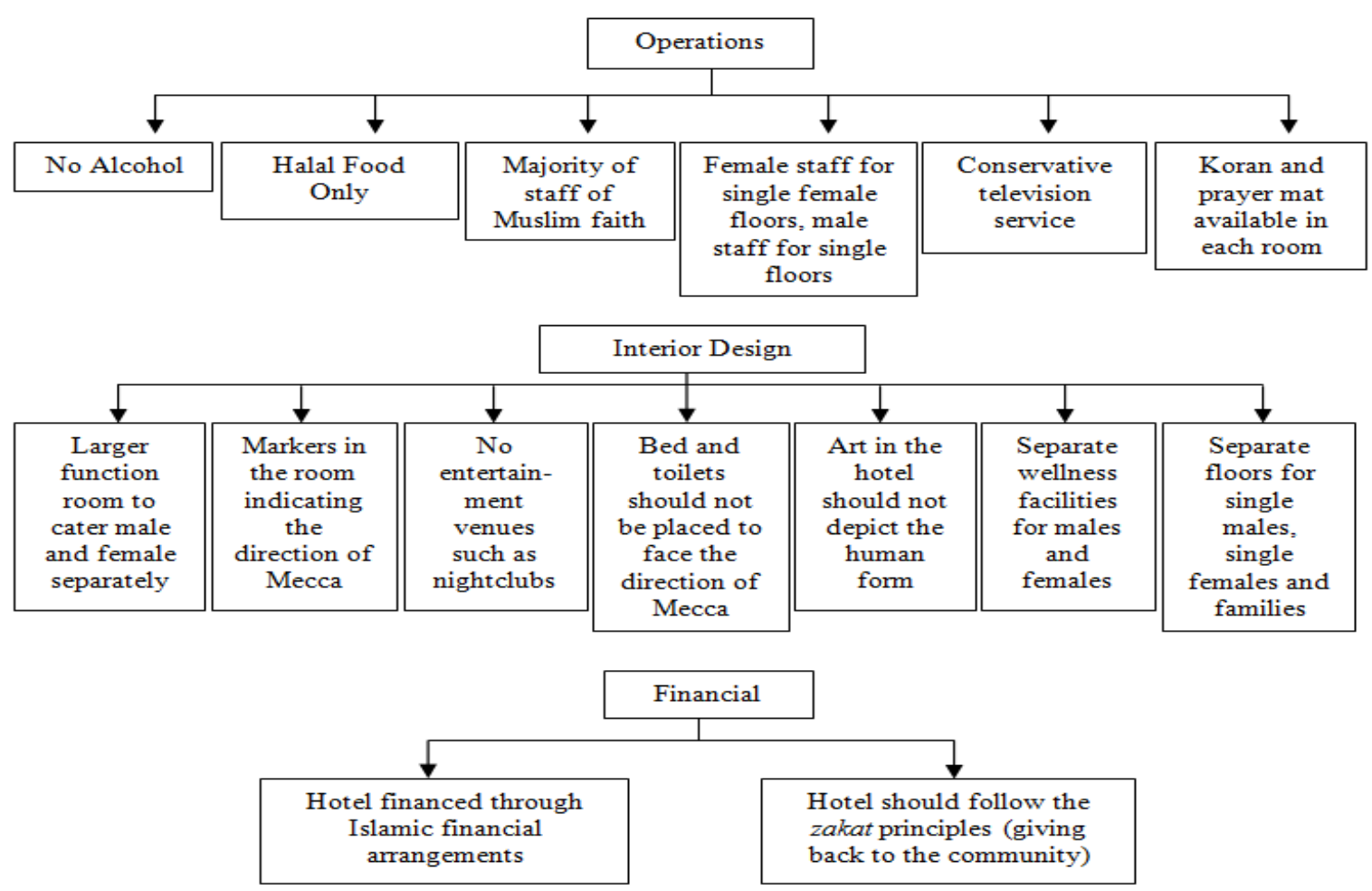

The above criteria were later being improvised by Henderson (2010) to include another 13 criteria consisting of, Halal food, no alcohol, Quran and prayer mats in each room, beds and toilet positioned so as not to face the direction of Mecca, bidets in the bathrooms, prayer rooms, appropriate entertainment, predominantly Muslim staff, Conservative staff dress, Separate recreational facilities for men and women, Guest dress code and Islamic funding.

Meanwhile, (Yusof \& Muhammad, 2013) suggested numerous attributes need to be addressed in regards to Shariah compliant hotel are as follows:

i. Proper Islamic staffs dress code requirements. A Muslim man should not reveal from his navel to his knee, while, a Muslim lady should at any rate cover her hair and body in free and unrevealing dress, clouding the points of interest of her body from people in general.

ii. Praying schedule in every hotel rooms. The schedule must be consistently updated (monthly or weekly) and must be from a legitimate Islamic religion council.

iii. Music foundation, for example, Quran recitation or nasyid (the nonexclusive
Malay expression for Islamic religious tunes) at the lobby, restaurant, elevators and public area.

iv. Good akhlaq trained staff. The akhlaq training must be implemented regularly in order to build the innate quality among hotel staffs.

v. Shop offering Islamic related items, such as, Islamic books, CDs, Islamic garments, halal sustenance and refreshments or some other items that can be considered as Islamic. The utensils and equipment in the premises should also be free from any haram stuffs. No alcoholic drinks should be served in the premise or restaurant.

According to Department Of Standards Malaysia, (2009), the second revision of MS 1500:2009 clearly stated all the procedures in preparing, handling, storage and producing the halal food, started from slaughtering, hygiene and sanitation aspect in food preparation, processing and handling, distributing and lastly serving to the customer. The labelling of the food as "halal'also should be observed.

Universal Crescent Standard Center (UCSC) took the initiative to formulate Islamic Quality Standard (IQS) on hotel to replace the conventional star 
rating. According to IQS there are 5 measuring factors for the hotel to comply with Islamic principles, such as the quality of physical facilities, the quality of services, halal foods, Muslim prayer facilities and hotel operation. IQS also identified 16 aspects for guest bedroom as in the Table 1 below:

Table 1: IQS aspects

\begin{tabular}{|c|c|}
\hline Criteria & Aspect \\
\hline Quality of Room & $\begin{array}{l}\text { Room is provided with key or key card } \\
\text { Basic furniture } \\
\text { Good flooring room are nice décor portray } \\
\text { Islamic features, } \\
\text { Qiblat signage, } \\
\text { Prayer mat, } \\
\text { Prayer schedule in all rooms, } \\
\text { Bedroom space is convenient with minimum } \\
\text { size of room is } 11.5 \text { sq. } \mathrm{m} \text { size and } 2.9 \text {. } \\
\text { Minimum bed size for single (190cms x } 90 \mathrm{cms} \\
=6 \mathrm{ft} 3 \text { ins } \mathrm{x} 3 \mathrm{ft} \text { ) and double (190cms x } 137 \mathrm{cms} \\
=6 \mathrm{ft} 3 \text { ins } \mathrm{x} 4 \mathrm{ft} 6 \text { ins), } \\
\text { Two sheets of blankets, bedspread and duvet } \\
\text { with cover, feather duvets and pillows are } \\
\text { used, } \\
\text { Good lighting, } \\
\text { Curtain size with large enough of width and } \\
\text { height to enhance privacy, } \\
\text { At least one full-length mirror, } \\
\text { Basic tea or coffee-making facilities with halal } \\
\text { ingredients, } \\
\text { Television with remote control and radio with } \\
\text { basic channels are available, } \\
\text { Fixed telephone is provided in every room } \\
\text { with hotel and room number is displayed on } \\
\text { the phone. }\end{array}$ \\
\hline
\end{tabular}

Source: (Omar \& Adaha, 2019)

A new standard MS2610:2015 was introduced in 2015 known as Muslim Friendly Hospitality Services (MFHS) launched by Islamic Tourism Centre Malaysia, MFHS standard covers three main components which are accommodation premise, tour packages and tourist guide. There are 5 main aspects required for accommodation premises which comprised of guest room, food \& beverages, prayer room, bathroom and recreational facilities. It was found out that there are 7 compulsory requirements to be obliged with but not limited to that condition only as illustrated in Table 2 below:

Table 2: Criteria of MFH as set in MS 2016: 2015

\begin{tabular}{|l|l|}
\hline Aspect & Requirement \\
\hline Room & $\begin{array}{l}\text { The room shall be kept clean and well } \\
\text { maintained. }\end{array}$ \\
\hline
\end{tabular}




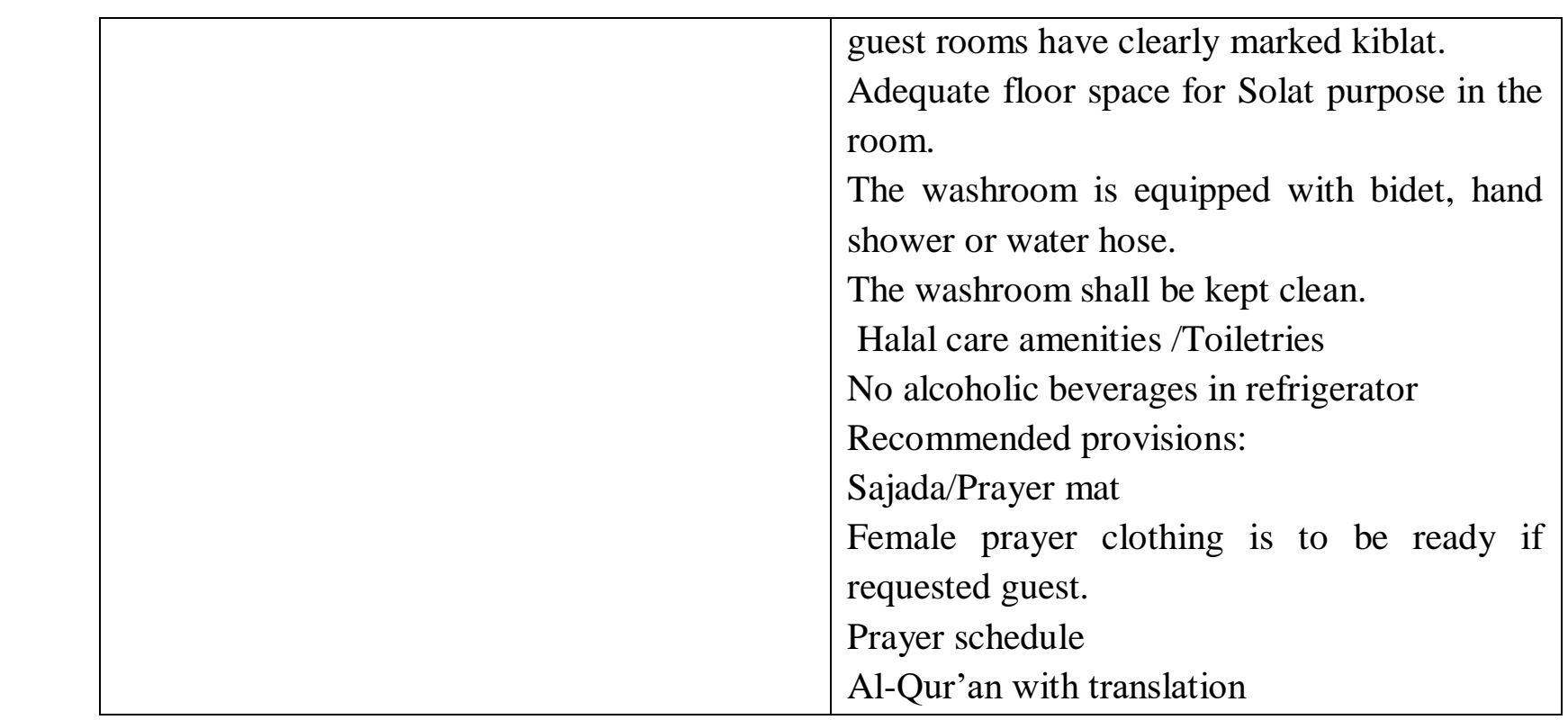

Source: (Department of Standards Malaysia, 2015)

In order to achieve $\mathrm{SCH}$, Syariah hotels must be operated based on Islamic financial system. Adam and Bakar (2014), claimed that Islamic finance requires participation in sharing the profit and loss among of all parties who involved in this finance enterprise. Islamic finance most prohibits interest (riba) as it is one of the root causes of some unfair

10. Analysis Of Interview With Two Prominent Public Authorities Directly Involve In Drafting Islamic Policies.

Some important data from interview analysis is presented in Table 3. economic.

Table 3: Criteria of Islamic Hotel and Maqasid Shariah

\begin{tabular}{|l|l|l|l|}
\hline \multicolumn{2}{|c|}{ Table 3 Information and Description } \\
\hline No & Questions & AUTHORITY 1 & AUTHORITY 2 \\
\hline 1 & $\begin{array}{l}\text { Any direction } \\
\text { or instruction } \\
\text { being made to } \\
\text { hoteliers on } \\
\text { SCH? }\end{array}$ & $\begin{array}{l}\text { No specific direction and } \\
\text { instructions made }\end{array}$ & $\begin{array}{l}\text { No specific directions and instructions } \\
\text { made }\end{array}$ \\
\hline 2 & $\begin{array}{l}\text { Do we have } \\
\text { interest on } \\
\text { Maqasid } \\
\text { Shariah? }\end{array}$ & $\begin{array}{l}\text { Yes, Maqasid is identified as the } \\
\text { main guide in structuring Shariah- } \\
\text { Compliant hotel. }\end{array}$ & $\begin{array}{l}\text { One main undergoing project is towards } \\
\text { streamlining guidelines and policy to be } \\
\text { implemented with the principle of } \\
\text { Maqasid Shariah. }\end{array}$ \\
\hline 3 & $\begin{array}{l}\text { Any current } \\
\text { practice } \\
\text { attributes link } \\
\text { to } \\
\text { Maqasid? }\end{array}$ & $\begin{array}{l}\text { Not much - It is only Halal Kitchen which } \\
\text { provides no pork and alcohol. } \\
\text {-Praying facilities in hotel room } \\
\text { was provided such as praying mat, } \\
\text { and Kiblat direction, }\end{array}$ & $\begin{array}{l}\text { 1) Staff is mandatory to perform Friday } \\
\text { prayers } \\
\text { 2) Availability of Islamic knowledge } \\
\text { training and the requirement for staff to } \\
\text { attend } \\
\text { 3) Staff need to cover their body } \\
\text { according as guided by Islam and hence } \\
\text { must be a Muslim. }\end{array}$ \\
\hline
\end{tabular}




\begin{tabular}{|c|c|c|c|}
\hline \multicolumn{4}{|c|}{ Table 3 Information and Description } \\
\hline & & & $\begin{array}{l}\text { Staff can perform fasting ritual. } \\
\text { 4) The financial investment must be } \\
\text { made on purely Islamic transactions. } \\
\text { 5) Al-Quran recitation. } \\
\text { 6) But in certain situation, small } \\
\text { percentage on Shariah non-compliant } \\
\text { investment is allowable but not on food } \\
\text { preparation. }\end{array}$ \\
\hline 4 & $\begin{array}{l}\text { Any Existing } \\
\text { Guidelines } \\
\text { and } \\
\text { Framework } \\
\text { was made? }\end{array}$ & $\begin{array}{l}\text { No official guidelines and } \\
\text { framework but periodic checking } \\
\text { and of hotel rooms for } \\
\text { unmarried couples activities and } \\
\text { halal kitchens are already been } \\
\text { practice. }\end{array}$ & $\begin{array}{l}\text {-No guidelines yet, but requirement to } \\
\text { appoint Hotel Shariah advisor is to be } \\
\text { followed. } \\
\text {-SIRIM Standards must be observed. } \\
\text { - Hotels are not forced to follow the } \\
\text { Shariah-compliant requirements, but } \\
\text { once applied, they must fully comply. }\end{array}$ \\
\hline 5 & $\begin{array}{l}\text { What are the } \\
\text { current status } \\
\text { of Halal } \\
\text { certification? }\end{array}$ & $\begin{array}{l}\text { Certification was already obtained } \\
\text { by } 25 \text { hotels and residence } \\
\text { operators. }\end{array}$ & $\begin{array}{l}\text { The function of certification is on each } \\
\text { state Islamic Councils. } \\
\text { JAKIM as federal authority has very } \\
\text { limited jurisdiction in addition the issue } \\
\text { of less manpower should be taken into } \\
\text { account. } \\
\text { The issues surrounding the law have also } \\
\text { been presented to the relevant ministry } \\
\text { for further discussion. }\end{array}$ \\
\hline 6 & $\begin{array}{l}\text { How hoteliers } \\
\text { response to } \\
\text { this issue? }\end{array}$ & $\begin{array}{l}\text { Majority give positive response. } \\
\text { However, the implementation } \\
\text { initiative is a bit slow. Therefore, } \\
\text { Some hotels took their own } \\
\text { initiative to control the Shariah } \\
\text { prohibitory activities }\end{array}$ & $\begin{array}{l}\text { Each hotel seems to have its own criteria } \\
\text { in complying with the Islamic rules in } \\
\text { addition to the compulsory one. } \\
\text { Some agreed that halal status has } \\
\text { marketing power but some are not } \\
\text { interested worrying of their profit. }\end{array}$ \\
\hline 7 & $\begin{array}{l}\text { Next action } \\
\text { Plans/ } \\
\text { Suggestions }\end{array}$ & $\begin{array}{l}\text { Proper implementation in the } \\
\text { future as it still unfinished work. }\end{array}$ & $\begin{array}{l}\text { Cooperating with Tourism Ministry is } \\
\text { essential and to propose the Shariah- } \\
\text { compliant hotel implementation to } \\
\text { states' Muftis. }\end{array}$ \\
\hline
\end{tabular}

Source: (Fieldwork, 2018)

A closer look to the above data showed that the pattern of responses between this two Informants were also similar. They seem to agree that a future proper drafting of inclusive Islamic hotel guidelines need to be aligned with the basic Maqasid' principles. The responses also portrayed that the existing guidelines and policies are still not enough to cater on a wide and various issues in the development of Islamic hotels. The below diagram represents a simple framework of how the current practice attributes of Shariah -Compliant Hotels or the muslims friendly hotels are in line with the basic Daruriyyat principles in Islam. According to (Ahmat, Ahmad Ridzuan, Din, Zainol, \& Razali, 
2015), Shariah covers every aspect of the life of faith, fiqh and morals which allows and prohibits certain things in addition to a set of guidelines to be followed by all Muslims. In drafting an inclusive guideline for hotel operators, it is well suggested that the intended guideline shall include the five basic principles of Maqasid which are preservation of religion, life, lineage, intellect and property. This means that the policy makers especially need to acknowledge the important of Maqasid Principles when drafting a proper policy of Islamic hotel.

\begin{tabular}{|c|c|c|}
\hline $\begin{array}{l}\text { MaqasidShariah } \\
\text { (Imam Al- } \\
\text { Ghazali) }\end{array}$ & \multicolumn{2}{|r|}{ Shariah-Compliant Hotel Attributes } \\
\hline $\begin{array}{l}\text { Protection of } \\
\text { Religion }\end{array}$ & Rooms & $\begin{array}{l}\text {-Qiblat direction, prayer mat and time schedule } \\
\text { for prayer } \\
\text {-Al-Quran } \\
\text { - Bathroom provide bidets } \\
\text {-All female floors } \\
\text { - Marriage certificates as a check-in procedure }\end{array}$ \\
\hline Protection of Life & $\begin{array}{l}\text { Food } \\
\text { and } \\
\text { Kitchen }\end{array}$ & $\begin{array}{l}\text { - Halal Kitchen (Utensils, Ingredients) } \\
\text {-Serving Halal food at all times } \\
\text {-Serving sahoor and iftar during Ramadhan }\end{array}$ \\
\hline $\begin{array}{l}\text { Protection of } \\
\text { Dignity }\end{array}$ & Facilities & $\begin{array}{l}\text {-Praying rooms by gender } \\
\text { - Swimming pool /scheduling by gender } \\
\text { - Spa and gymnasium by gender } \\
\text { - Separate facilities between male and female, } \\
\text { - Azan } \\
\text { - Congregational Jumaat prayer }\end{array}$ \\
\hline $\begin{array}{l}\text { Protection of } \\
\text { Wealth }\end{array}$ & Staff & -Shariah-compliant dress code \\
\hline & $\begin{array}{c}\text { Activities } \\
\text { /event }\end{array}$ & -Entertainment for family and by gender \\
\hline & Finance & $\begin{array}{l}\text {-Zakat } \\
\text { •Sadaqah } \\
\text { •Islamic debt and investment management }\end{array}$ \\
\hline
\end{tabular}

Based on the above figure, the ultimate concern in hotel industry which can be primarily discussed here is in terms of gender separation in hotel accommodation. This phenomenon has generally become the accepted norm and practice and previously, gender segregation in the hotel was not seen as an important element in the hotel sector. However, a good remark need to be highlighted here as recently, few big hotels were actually put up some efforts in implementing this concept and it is highly recommended in Islam because it upholds the protection of life and heredity. Prophet Muhammad (SAW) clearly practiced segregation between men and women by way of segregation in the mosque. Hence male and female entrance will be different so that no mixture between the genders. Separation is also seen as an idea to preserve dignity and lineage. In this context, Shariah expressly prohibits Muslims from engaging in fornication and adultery.

In term of Islamic staffs dress code requirements, a man should not reveal from his navel to his knee. While, a Muslim lady should at any rate conceal and cover her full hair and body, clouding the points of interest of her body from any people in general. The shrewdness behind this clothing regulation is to limit sexual allurement and corruption in the public eye however much as could 
reasonably be expected for both men and ladies. Complying with this clothing regulation is a type of acquiescence to God. Islam precludes any sex request and physical allurement outside of marriage. Interestingly, Islam energizes sex claim and physical fascination for both men and ladies inside the security between wedded couples.

Good akhlaq training for staff is needed as it is characterized as a set of accepted rules for an Islamic lifestyle. The motivation behind this profound preparing is to feed and create moral ideals among hotel staff. This training must be executed regularly in order to continuously instill the good akhlaq with an Islamic value among hotel staffs. Therefore, this directly matched with the principles of Protection of Lineage and dignity as one of the five main basic principles of Maqasid Shariah. In closing all roads that lead to evil, free mixing of the sexes and, the wearing of inappropriate and revealing clothing are strictly prohibited in Islam.

\section{CONCLUSIONS}

The discussion throughout the data analysis showed that no specific guidelines and policies being drafted on Islamic based hotels either on "Shariah compliant hotels" or "Muslim Friendly Hotel" at the moment (except that MS 2016: 2015). The public authorities are actually aware on this issue as well as the demand and interest of some hotels in obtaining the certification and recognition towards Shariah-compliant hotel status. Therefore, currently, consultation and monitoring are already in place towards that establishment. Furthermore, a content analysis towards the existing policies and interview conducted proved that the application of the Maqasid criteria could accommodate in the planning and design of laws and policies as well as the physical design of hotel rooms. The findings help the future hotel developers to get ready with an idea on how to expand their businesses in the future and thus, making Malaysia as a preferred destination. However, as the implementations of "Shariah Compliant Hotel" or Muslim friendly hotels at this moment is only by choice and was not made compulsory to hotel operators, the full commitment from the hotel operators may become a challenge to the public authorities.

\section{REFERENCES}

[1] Afridi, M. A. K. (2016). Maqasid alshari'ah and preservation of basic rights: Under the theme" Islam and its perspectives on global \& loca contemporary challenges. Journal of Education and Social Sciences, 4(1).

[2] Ahmat, C., Ahmad Ridzuan, A. H., Din, N., Zainol, N., \& Razali, M. A. (2015). Syariah compliant hotel: The concept and practices/Nur'Hidayah Che Ahmat....et al.]. Journal of Tourism, Hospitality \& Culinary Arts (JTHCA), 7(2).

[3] Arshad, M. I., Iqbal, M. A., \& Shahbaz, M. (2018). Pakistan tourism industry and challenges: a review. Asia Pacific Journal of Tourism Research, 23(2), 121-132.

[4] Battour, M., \& Ismail, M. N. (2016). Halal tourism: Concepts, practises, challenges and future. Tourism management perspectives, 19, 150-154. doi: 10.1016/j.tmp.2015.12.008

[5] Berg, B. L. (2004). Methods for the social sciences. Qualitative Research Methods for the Social Sciences. Boston: Pearson Education.

[6] Chanin, O., Khunchumnan, P., Amphansookko, S., Thongyai, K., Rodneum, J., \& Sriprasert, P. (2015). Guidelines on health tourism management for middle eastern tourists in Phuket province. Procedia Computer Science, 65, 1146-1153. doi: 10.1016/j.procs.2015.09.031

[7] Eid, R., \& El-Gohary, H. (2015). Muslim tourist perceived value in the hospitality and tourism industry. Journal of Travel Research, 54(6), 774-787.

[8] Elasrag, H. (2016). Halal industry: Key challenges and opportunities: Hussein Elasrag.

[9] . Global Muslim Travel Index 2018. (2019), from 
https://www.crescentrating.com/reports/m

astercard-crescentrating-global-muslim-

travel-index-gmti-2018.html.Retrieved 11

December 2019,

[10] Hassan, H., Abd Ghadas, Z. A., \& Rahman, N. A. (2012). The Myth of Corporate Personality': A comparative Legal Analysis of the Doctrine of Corporate Personality of Malaysian and Islamic Laws. Australian Journal of Basic and Applied Sciences, 6(11), 191-198.

[11] Jais, A. S. (2016). Shariah compliance hotel: Concepts and design. Malaysia: Koperasi Politeknik Merlimau Malaka Berhad.

[12] Jeaheng, Y., Al-Ansi, A., \& Han, H. (2019). Halal-friendly hotels: Impact of halalfriendly attributes on guest purchase behaviors in the Thailand hotel industry. Journal of Travel \& Tourism Marketing, 36(6), 729-746. doi: 10.1080/10548408.2019.1631940

[13] Kamali, M. H. (2000). Principles of Islamic Jurisprudence, Kuala Lumpur: Ilmiah Publishers, 2000, p: 139.

[14] . Malaysia Establishes Official Recognition for Halal-Friendly Hotels. . (2019), from <https://www.ttgasia.com/2019/07/25/mal aysia-establishes-official-recognition-forhalal-friendly-hotels/> [Accessed 16 November 2019].

[15] Musa, A., Kadir, S. A., Ibrahim, M., Jusoh, N., Tahrim, S. N. C., \& Din, N. M. (2017). Developing a proper framework towards shariah-compliant hotel in Malaysia: identifying opportunities and challenges. Journal of Global Business and Social Entrepreneurship (GBSE), 1(4), 103-111.

[16] Musa, A., Kadir, S. A., Ibrahim, M., Jusoh, N., Tahrim, S. N. C., \& Din, N. M. (2019). Authorities Perspectives Towards the Implementation of Shariah-Compliant Hotel in Malaysia.

[17] Nor, A. H. M., Alias, M. N., Samsudin, A., Omar, A. F., Ibrahim, I. A., Laluddin, H., . . Manap, N. A. (2012). Application of the principles of Maqasid Shari'ah in administration of the Islamic countries. Advances in Natural and Applied Sciences, 6(6), 847-852.

[18] Omar, C. M. C., \& Adaha, N. M. A. (2019) AN OPERATIONAL SHARIAH COMPLIANT HOTEL REQUIREMENTS: MALAYSIA EXPERIENCE. Journal of Hospitality and Networks, 1(1), 23-33.

[19] Rahman, N. A., Faudzi, M. H. M., Ahamat, H., \& Ghadas, Z. A. A. (2016). Competition law and the Malaysian financial services market: an analysis of the structure and level of competition in the market. International Journal of Monetary Economics and Finance, 9(4), 353-362.

[20] Rosenberg, P., \& Choufany, H. M. (2009). Spiritual lodging-The Sharia-compliant hotel concept. HVS Global Hospitality Services-Dubai.

[21] Salleh, N. Z. M., Hamid, A. B. A., Hashim, N. H., \& Omain, S. Z. (2014). The practice of Shariah-compliant hotel in Malaysia. International Journal of Trade, Economics and Finance, 5(1), 26.

[22] Samori, Z., \& Sabtu, N. (2014). Developing halal standard for Malaysian hotel industry: An exploratory study. Procedia-Social and Behavioral Sciences, 121, 144-157. doi: 10.1016/j.sbspro.2014.01.1116

[23] Şen Küpeli, T., Koc, B., \& Hassan, A. (2018). Understanding religion-based tourism terminology in the context of the hotel industry. Anatolia, 29(2), 252-266. doi: 10.1080/13032917.2017.1414448

[24] Shafaei, F., \& Mohamed, B. (2017). Malaysia's branding as an Islamic tourism hub: An assessment. Geografia-Malaysian Journal of Society and Space, 11(1).

[25] Suid, I. S., Nor, N. A. M., \& Omar, H. (2017). A review on islamic tourism and the practical of islamic attributes of destination in tourism business. International Journal of Academic Research in Business and 
Social Sciences, 7(12), 255-269. doi: 10.6007/ijarbss/v7-i12/3609

[26] Sulaiman, S. S., \& Maidin, A. J. (2018). Harmonising the Attributes of Shariah Compliant Hotel with the Concept of Sustainable Hotel Development Under the Town and Country Planning Act 1976. Paper presented at the Proceedings of the 3rd International Halal Conference (INHAC 2016).

[27] Tarrant, C. (2010). Middle East hotel gusts express high interest in sharia compliant hotels. United Kingdom.

[28] Yusof, M. F. M., \& Muhammad, M. Z. (2013). Introducing Shariah compliant hotels as a new tourism product: the case of Malaysia.

[29] Yusuf, S. (2009). The real sense of Shariah hospitality concept. Paper presented at the World Halal Forum. 